\title{
Evaluation of Cowpea Genotypes for Use as a Cover Crop
}

\author{
Howard F. Harrison, ${ }^{1}$ Judy A. Thies, and Richard L. Fery \\ U.S. Vegetable Laboratory, U.S. Department of Agriculture, Agricultural \\ Research Service, 2700 Savannah Highway, Charleston, SC 29407
}

\section{J. Powell Smith \\ Clemson University, Edisto Research and Education Center, 64 Research Road, Blackville, SC 29817}

Additional index words. Vigna unguiculata, weed suppression, root knot nematode, Meloidogyne incognita

\begin{abstract}
A preliminary screening experiment was conducted to evaluate 47 cowpea [Vigna unguiculata (L.) Walp.] genotypes for use as a weed-suppressing cover crop. Of these, 11 were selected for further testing on the basis of vigorous growth and weedsuppressing ability. In a field experiment repeated over 4 years, the selected genotypes were not different from the leading cover crop cultivar 'Iron Clay' in biomass production. Vigor ratings, vine growth ratings, and canopy widths of some genotypes exceeded those of 'Iron Clay' Vigor ratings and canopy measurements were efficient selection criteria that could be useful for breeding cover crop cowpea cultivars. All except one selection were highly resistant to southern root knot nematode [Meloidogyne incognita (Kofoid and White) Chitwood], and the selections varied in seed size, photoperiod, and response to foliar diseases.
\end{abstract}

The adoption of sustainable and organic agricultural production in recent years has resulted in an increased use of cover crops. Cover crops improve soil properties, including tilth, water capacity, fertility organic matter, and temperature (Abdul-Baki et al., 1995, 1996, 1997; Teasdale and Abdul-Baki, 1997; Teasdale and Shirley, 1998). They may also positively affect pest control by suppressing weeds and other pests and reducing runoff or groundwater infiltration of pesticides. Traits that make cowpea an excellent warm season cover crop are tolerance to heat and drought stress, ability to grow well in sandy, poor, acidic soils, and high biomass production with high nitrogen content while requiring little fertilization. Hall et al. (2003) suggested that an ideal cover crop cowpea cultivar should have the following attributes: short photoperiod, a vigorous shoot type to suppress weeds, small, round seeds to facilitate harvest and planting, and resistance to nematodes and other pests.

Vegetative cowpea varieties were grown extensively in the southern United States as a warm season forage, cover, or green manure crop before the development of pesticides and synthetic nitrogen fertilizer. With the onset of modern agricultural practices, forage cowpea production waned, and seeds

\footnotetext{
Received for publication 23 Dec. 2005. Accepted for publication 7 Apr. 2006. Mention of a trademark name or proprietary product does not constitute a warranty or guarantee by the U.S. Dept. of Agric. nor does it imply exclusion of other products that may also be suitable.

${ }^{1}$ To whom reprint requests should be addressed; e-mailhharrison@saa.ars.usda.gov.
}

of most of the old forage cultivars are not commercially available. Cowpea genotypes vary greatly in growth habit; however, relatively little research has been reported on the effect of growth habit on biomass production or competition with weeds. Remison (1978) found that a climbing cowpea cultivar was less affected by weed interference than a semierect variety in an African pole-supported production system. Nangju (1978) reported that cultivars with taller growth habit and high leaf area indices were most competitive against weeds. Wang et al. (2004) compared the competitiveness of three cowpea genotypes with different growth habits (erect, semierect, and prostrate) with two weed species and concluded that the genotype with an upright growth habit was more competitive as a result of a greater ability to shade competing weeds. Many modern U.S. cultivars of the vegetable cowpea types that are classified as southernpea are determinate and compact in growth with relatively sparse foliage. This growth habit has been preferentially developed to facilitate mechanical harvest, but some researchers have speculated that compact varieties are susceptible to yield reduction by weed interference. 'Iron Clay' is currently widely marketed as a cover crop and wildlife feed cowpea cultivar, and it has been used extensively in cover crop research (Harrison, et al., 2004, Roberts et al., 2005; Wang et al., 2004). It probably originated as a mixture of two forage cultivars, Clay and Iron. 'Iron Clay' has vigorous growth, short photoperiod, and root knot nematode resistance, which are desirable traits for a cover crop (Hall et al., 2003). However, it tends to produce a high proportion of hard seeds, and the pods shatter under dry conditions, which may create a weed problem for subsequent crops. The objectives of this research were to develop screening methods to identify cowpea genotypes suitable for use as a cover crop, identify candidate cover crop cowpea genotypes, and evaluate selected genotypes in comparison with the standard cultivar, 'Iron Clay'.

\section{Materials and Methods}

All experiments were conducted at the U.S. Vegetable Laboratory research farm, Charleston, SC. The soil type was a Yonges loamy sand (Aeric Paleaquults) with less than $1 \%$ organic matter and $\mathrm{pHs}$ between 6.3 and 6.8. Fields were not fertilized during the year they were used. Preliminary screening trials were conducted in 1997 and 1999 to select cowpea genotypes that appeared most suitable for use as a weed-suppressing cover crop. The cowpea genotypes evaluated in this study included forage cowpea and southernpea cultivars, and experimental genotypes and accessions maintained by the U.S. Vegetable Laboratory cowpea breeding program (Arlington, Blue Goose, Bradham Victor, Calif. Blackeye \#5, California Blackeye \#46, Clay, Cornfield English, Coronet, Elvington, Graham, Hardee, Iron, Iron Clay, Knuckle Purple Hull, Miss. Silver, New Era, Prima, Ramshorn Blackeye, Whippoorwill, White Acre, and experimental lines or accessions with U.S. numbers 44, 325, 432, 706, 707, 709, 708, 709, 710, 711, 735), experimental breeding lines or accessions from the University of California, Riverside cowpea breeding program (UCR numbers 24, 671, $730,779,1340,2840,3038,3139,3295)$, and several landraces of unknown origin. The screening study was arranged in a randomized complete block design with four replications. Plots consisted of four hills spaced equidistantly at $1 \mathrm{~m}$ with three seeds planted by hand in each hill. During the growing season, cowpeas were evaluated for general vigor, vine growth rate, and weed suppression. Canopy width and height measurements were recorded.

Data and observations from the preliminary screening experiments were used to select 11 cowpea genotypes, which were subsequently evaluated in field experiments in 2000 through 2003. The selections included five U.S. forage cultivars (Graham, Hardee, Speckled Graham, Iron Clay, and Tyler), a University of California experimental genotype (UCR 1340), a cultivar from the International Institute of Tropical Agriculture, Nigeria (Lalita), and four landraces that were collected in South Carolina $(\mathrm{N}-1-3$, N-3, Red Seeded Viny, and Local Volunteer). Planting dates were 26 June 2000, 24 May 2001, 22 May 2002, and 25 June 2003. Cowpea seeds were hand planted at 10 seeds $\cdot \mathrm{m}^{-1}$ row on raised narrow beds spaced $1 \mathrm{~m}$ apart. The experiment was arranged in a randomized complete block design with five replicates in 2000 and 2001. Plots were $3 \mathrm{~m}$ (three rows) $\times 6 \mathrm{~m}$ with $2 \mathrm{~m}$ between 
plots. Metolachlor herbicide [2-chloro- $\mathrm{N}$-(2ethyl-6-methylphenyl)-N-(2-methoxy-1methylethyl)acetamide] was applied at $1.6 \mathrm{~kg} \cdot \mathrm{ha}^{-1}$ and watered in with $\approx 2 \mathrm{~cm}$ of overhead irrigation within $24 \mathrm{~h}$ after planting. Plots were tilled and hoed to reduce weed interference. Between 10 and 11 weeks after planting, cowpea plants were rated for general vigor on a scale of 1 to 5 where $1=$ lowest vigor and $5=$ highest vigor. Vine growth rate was also rated on a 1 to 5 scale where $1=$ no vines and $5=$ extensive vine growth and climbing ability. Canopy heights and widths were measured. Width was estimated by doubling the distance from the center of the outer row to the canopy edge. Prostrate vine growth that extended beyond the upright portion of the canopy was not considered in the width measurement. Cowpea biomass production was determined by weighing the shoot tissue harvested from a $1-\mathrm{m}^{2}$ quadrant from the middle of each plot. Shoot tissue was ground in a mulch grinder, and a $1-\mathrm{kg}$ sample of the tissue from each plot was dried in a forced air drier and the moisture percentage was used to convert biomass to dry weight. A small sample of the dried shoot tissue was saved for total nitrogen content determination by the Clemson University Agricultural Service Laboratory, Clemson, SC.

The experiment was arranged in a splitplot design with five replications in 2002 and 2003. Main plots were $6 \times 6 \mathrm{~m}$, and subplots were $3 \mathrm{~m} \times 6 \mathrm{~m}$. Cowpeas were planted as described. The southernpea cultivar, Charleston Greenpack, was included in this experiment as a noncompetitive control. Main plot treatments were the 12 cowpea genotypes. Subplot treatments were a weedy treatment that received no weed control and a weeded treatment with weed control as described above. Vigor and vine growth ratings, canopy height and width measurements, and shoot biomass were collected from the weeded subplots as described. The 4 years of vigor and vine growth ratings, canopy measurements, and biomass data were combined and analysis of variance was performed using a two-way factorial analysis where genotype was the first factor and year was the second factor. The weeded subplots in the 2002 and 2003 experiments were the same size and received the same cultural practices and weed management as plots in the 2000 and 2001 experiments, and the data from the weeded subplots were included in the factorial analyses. Data from the weedy subplots or from "Charleston Greenpack" plots were not included in the factorial analyses. Biomass data from the 2002 and 2003 experiments were also analyzed separately to compare weedy and weed-free subplots. Duncan's multiple range test at $P \leq 0.05$ was used to separate genotype means.

The cowpea genotypes were evaluated for resistance to southern root-knot nematode, race 3 , in a greenhouse experiment. The experimental design was a randomized complete block with four replicates. Each plot consisted of five seeds of an entry planted
$10 \mathrm{~cm}$ apart and $2 \mathrm{~cm}$ deep in a greenhouse bench containing soil ( 2 parts sand: 1 part loamy sand) that was steam pasteurized for $6 \mathrm{~h}$. Nematode inoculum was cultured on 'Rutgers' tomato (Solanum lycopersicon L.) in the greenhouse. Eggs were extracted from tomato roots using $0.5 \% \mathrm{NaOCl}$. Seeds were planted on 6 Aug. 2002 and the soil surrounding each seed was infested with ca. 3000 M. incognita race 3 eggs suspended in $5 \mathrm{ml}$ $\mathrm{H}_{2} \mathrm{O}$. The greenhouse temperatures ranged from 24 to $34{ }^{\circ} \mathrm{C}$. On 24 Sept. 2002 , the roots of the plants were lifted, washed, and evaluated for resistance to root-knot nematode using a 1 to 5 rating system, where $1=0 \%$ to $3 \%$ of root system galled or covered with egg masses, $2=4 \%$ to $25 \%, 3=26 \%$ to $50 \%$, $4=51 \%$ to $79 \%$, and $5=\geq 80 \%$ of root system galled or covered with egg masses. Gall and egg mass indices (GI and EMI, respectively) $\leq 2$ are considered highly resistant, GI $=2.1$ to 2.9 are moderately resistant, and GI $\geq 3.0$ are susceptible.

Seed size and seedcoat color were recorded. In 2002, two diseases, anthracnose incited by Colletotrichum sp. and southern blight incited by Sclerotium rolfsii Sacc (diagnosed by the Clemson University Plant Problem Clinic, Clemson, SC), were more severe than in other years. Genotypes varied in response to both diseases, and they were rated as susceptible, intermediate, or resistant based on the severity of the symptoms. Each year, the cowpeas were left in the field for observation until they were killed by frost.

\section{Results and Discussion}

Ten to 11 weeks after planting was chosen as the interval to take rating and growth measurement data, because at this point, the canopies of the cover crop genotypes were well developed but they were not senescent. All 11 cowpea genotypes selected in the preliminary screening study proved to be relatively vigorous, high biomass producers (Table 1). Although there were differences between genotypes for all measurements, most genotypes were not different. Factorial analysis indicated that the effect of years was greater than the effect of genotype for vigor rating and biomass, and was highly significant for vine growth and canopy width. Environmental factors that probably contributed to the differences between years include rainfall, temperatures, planting date, and the incidence of diseases and insects. Rainfall during the 11-week interval after planting was $53.7,48.1,23.4$, and $53.4 \mathrm{~cm}$ in 2000 , 2001, 2002, and 2003, respectively. The significant interactions between genotype and year for vigor ratings, vine growth rating, height, and width point to the need for extensive testing over several environments to identify broadly adapted cover crop genotypes. For instance, UCR 1340 produced the greatest biomass for the 4-year average; this was the result of very high biomass production in 2002 (Table 2), the driest growing season. In other years, UCR 1340 biomass production was not as great (data not presented), which may indicate that it is adapted to dry conditions.

The 2002 and 2003 experiments were arranged in a split-plot design in which weeds were not controlled in one of the two subplots. A number of common annual broadleaf and grass weed species and yellow nutsedge (Cyperus esculentus L.) occurred in the weedy plots; however, spatial variation in species and population was great. Overall, biomass production by the cowpea genotypes was not greatly affected by weed interference in either year (Table 2). The cowpea selections grown in weedy plots averaged $96 \%$ and $90 \%$ of the biomass production of the weed free plots in 2002 and 2003, respectively. Weed pressure was lower in 2002 than in 2003 as indicated by greater weed biomass and reduction of cowpea biomass in 2003. This may have been the result of higher rainfall in 2003 that promoted vigorous weed growth. Weed biomass was greater in weedy subplots of the southernpea cultivar, Charleston Greenpack, than in the cover crop selections in 2002, and Charleston Greenpack biomass was reduced more by weed interference than the selections in 2003. These

Table 1. Average vigor ratings, vine growth ratings, canopy heights, canopy widths, and biomass production of 11 cowpea genotypes in field experiments conducted in 2000, 2001, 2002, and 2003.

\begin{tabular}{|c|c|c|c|c|c|}
\hline Genotype & Vigor rating $^{z}$ & Vine growth rate & Height $(\mathrm{cm})$ & Width (cm) & Biomass $\left(\mathrm{g} \mathrm{dw} \cdot \mathrm{m}^{-2}\right)$ \\
\hline Graham & $3.7 \mathrm{~b}$ & $2.9 \mathrm{cde}$ & $63 \mathrm{ab}$ & 101 bcd & $388 \mathrm{c}$ \\
\hline Hardee & $3.9 \mathrm{ab}$ & $3.4 \mathrm{ab}$ & $62 \mathrm{ab}$ & $108 \mathrm{ab}$ & $412 \mathrm{abc}$ \\
\hline Iron Clay & $3.7 \mathrm{~b}$ & $2.0 \mathrm{f}$ & $65 \mathrm{a}$ & 94 cde & $420 \mathrm{abc}$ \\
\hline Speckled Graham & $3.9 \mathrm{ab}$ & $3.0 \mathrm{bcd}$ & $59 \mathrm{abc}$ & 99 bcd & $410 \mathrm{bc}$ \\
\hline Tyler & $3.6 \mathrm{bc}$ & $3.3 \mathrm{abc}$ & $62 \mathrm{ab}$ & $98 \mathrm{~cd}$ & $406 \mathrm{bc}$ \\
\hline Lalita & $3.8 \mathrm{ab}$ & $2.5 \mathrm{ef}$ & $58 \mathrm{bc}$ & 92 de & $386 \mathrm{c}$ \\
\hline $\mathrm{N}-1-3$ & $3.8 \mathrm{ab}$ & $2.5 \mathrm{ef}$ & $63 \mathrm{ab}$ & $101 \mathrm{bcd}$ & $413 \mathrm{abc}$ \\
\hline $\mathrm{N}-3$ & $3.6 \mathrm{~b}$ & $2.4 \mathrm{ef}$ & $58 \mathrm{bc}$ & 89 e & $450 \mathrm{ab}$ \\
\hline UCR 1340 & $3.9 \mathrm{ab}$ & $3.3 \mathrm{abc}$ & $61 \mathrm{abc}$ & $103 \mathrm{bc}$ & $472 \mathrm{a}$ \\
\hline Red seed viny & $4.2 \mathrm{a}$ & $3.7 \mathrm{a}$ & $64 \mathrm{a}$ & $114 \mathrm{a}$ & $405 \mathrm{bc}$ \\
\hline Local volunteer & $3.6 \mathrm{~b}$ & $\begin{array}{c}2.6 \mathrm{def} \\
\text { ANOVA }^{\mathrm{z}}\end{array}$ & $52 \mathrm{c}$ & $100 \mathrm{bcd}$ & $436 \mathrm{abc}$ \\
\hline Block & $0.98^{\mathrm{NS}}$ & $1.172^{\mathrm{NS}}$ & $5.932 * * *$ & $0.191^{\mathrm{NS}}$ & $0.245^{\mathrm{NS}}$ \\
\hline Genotype & $2.533 * *$ & $14.707 * * *$ & $5.004^{* * *}$ & $10.441 * * *$ & $2.095^{*}$ \\
\hline Year & $19.854 * * *$ & $44.856 * * *$ & $1.350^{\mathrm{NS}}$ & $100.162 * * *$ & $74.611 * *$ \\
\hline Genotype $\times$ year & $2.154 * * *$ & $5.263 * * *$ & $2.004 * *$ & $2.253 * * *$ & $0.976^{\mathrm{NS}}$ \\
\hline
\end{tabular}

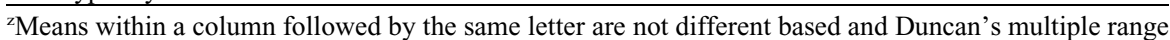
test at $P \leq 0.05$.

$\mathrm{NS}, *, * *, * * * \mathrm{~F}$ values for the sources of variation $\mathrm{Ns}$, or significant at $P<0.05,0.01,0.001$, respectively. 
Table 2. Biomasses of 11 cover crop cowpea genotypes grown with and without weed management and weed biomasses in subplots without weed management in 2002 and 2003.

\begin{tabular}{|c|c|c|c|c|c|c|}
\hline & \multicolumn{3}{|c|}{$2002\left(\mathrm{~g} \mathrm{dw} \cdot \mathrm{m}^{-2}\right)$} & \multicolumn{3}{|c|}{$2003\left(\mathrm{~g} \mathrm{dw} \cdot \mathrm{m}^{-2}\right)$} \\
\hline & $\begin{array}{l}\text { Cowpea } \\
\text { weeded }\end{array}$ & $\begin{array}{c}\text { Cowpea }^{z} \\
\text { weedy }\end{array}$ & Weeds & $\begin{array}{l}\text { Cowpea } \\
\text { weeded }\end{array}$ & $\begin{array}{l}\text { Cowpea } \\
\text { weedy }\end{array}$ & Weeds \\
\hline Graham & 483 & 495 & 15 & 356 & 317 & 175 \\
\hline Hardee & 491 & 437 & 40 & 379 & 326 & 117 \\
\hline Iron Clay & 520 & 450 & 20 & 429 & 377 & 156 \\
\hline Speckled Graham & 525 & 471 & 48 & 421 & 410 & 227 \\
\hline Tyler & 544 & 541 & 24 & 437 & 416 & 201 \\
\hline Lalita & 451 & 445 & 17 & 411 & 328 & 126 \\
\hline $\mathrm{N}-1-3$ & 499 & 482 & 13 & 473 & 419 & 165 \\
\hline $\mathrm{N}-3$ & 518 & 535 & 1 & 464 & 380 & 199 \\
\hline UCR 1340 & 652 & 666 & 5 & 399 & 430 & 134 \\
\hline Red seed viny & 537 & 535 & 16 & 391 & 373 & 137 \\
\hline Local volunteer & 583 & 531 & 38 & 460 & 378 & 147 \\
\hline Charleston Greenpack & 511 & 458 & 109 & 407 & 262 & 156 \\
\hline $\operatorname{LSD}_{0.05^{2}}$ & 126 & 93 & 55 & NS & 92 & NS \\
\hline
\end{tabular}

${ }^{\mathrm{z}} \mathrm{LSD}_{0.05}$ for comparing means within a column.

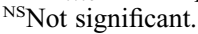

observations demonstrate the less competitive growth habit of the southernpea cultivar.

Root-knot nematodes are an important pest of vegetable crops, including cowpea, in the southern United States and worldwide. Reactions of the 10 cowpea cultivars evaluated for resistance to root-knot nematodes ranged from 1.1 to 5.0 for root gall and egg mass indices (GI and EMI, respectively) (Table 3). Nine selections (Graham, Hardee, Speckled Graham, Tyler, N-1-3, N-3, UCR 1340, Red Seed Viny, and Local Volunteer) were highly resistant; GI and EMI ranged from 1.1 to 1.9 and 1.1 to 1.8 , respectively. 'Lalita' was the only selection that was susceptible $(\mathrm{GI}=5.0$ and $\mathrm{EMI}=5.0)$. The control cultivars performed as expected. Mississippi Silver was resistant $(\mathrm{GI}=1.2, \mathrm{EMI}=$ 1.2), Pinkeye Purple Hull was susceptible $(\mathrm{GI}=4.0$, EMI $=4.1)$, and New Era was highly susceptible $(\mathrm{GI}=5.0, \mathrm{EMI}=5.0)$. The nine resistant selections should be useful as rotational cover crops or mulches for managing root-knot nematodes in vegetable cropping systems or as sources of root-knot nematode resistance in the development of new cowpea cover crop cultivars. The availability of cowpea genotypes that suppress both weeds and root-knot nematodes are much needed in the management of both of

these important pests of vegetable crops. The pending removal and current reduction in use of methyl bromide, which is the primary method for controlling root-knot nematodes and weeds in many vegetable crops, heighten the importance of developing nonchemical methods for managing both weed and nematode pests in high-value vegetable crops.

Seed size ranged from 6.6 to $21.0 \mathrm{~g} \cdot(100$ seeds $)^{-1}$ and seedcoat color was variable (Table 3). The small seed size of 'Local volunteer' was among the desirable features of an ideal cover crop cowpea listed by Hall et al. (2003). Preliminary observation of the severity of the symptoms of anthracnose and southern blight in 2002 indicated that the selections may vary in tolerance. More extensive evaluation is needed to verify the differences. Average nitrogen contents of cowpea shoots determined at 10 weeks after planting were $2.4 \%$ and $3.0 \%$ of the dry weight in 2001 and 2002 , respectively, and selections were not different in nitrogen content in either year (data not presented). In a previous study (Harrison et al., 2004), we found that a mature 'Iron Clay' canopy contained $205 \mathrm{~kg} \cdot \mathrm{ha}^{-1}$ total nitrogen. Based on biomass production and nitrogen content, it seems likely that all genotypes would contribute a similar amount of nitrogen to rotational crops. Aguiar et al.
Table 3. Seed size, seedcoat color root knot nematode gall and egg mass indices, and disease response of 11 cowpea genotypes selected for evaluation for use as a cover crop.

\begin{tabular}{|c|c|c|c|c|c|c|}
\hline \multirow[b]{2}{*}{ Genotype } & \multirow{2}{*}{$\begin{array}{c}\text { Seed } \\
\text { size }(\mathrm{g} / 100 \\
\text { seeds })^{-1}\end{array}$} & \multirow{2}{*}{$\begin{array}{l}\text { Seedcoat } \\
\text { color }(\mathrm{g} / 100 \\
\text { seeds })^{-1}\end{array}$} & \multicolumn{2}{|c|}{$\begin{array}{l}\text { Root knot nematode } \\
\text { index }^{z}\end{array}$} & \multicolumn{2}{|c|}{$\begin{array}{l}\text { Disease } \\
\text { response }^{\mathrm{y}}\end{array}$} \\
\hline & & & Gall & Egg mass & $\overline{\mathrm{AN}}$ & SB \\
\hline Graham & 15.6 & Tan & $1.1 \mathrm{c}$ & $1.1 \mathrm{c}$ & $\mathrm{R}$ & $\mathrm{R}$ \\
\hline Hardee & 21.0 & Red & $1.2 \mathrm{c}$ & $1.2 \mathrm{c}$ & $\mathrm{R}$ & $\mathrm{R}$ \\
\hline Iron Clay & 12.4 & Brown & - & - & I & I \\
\hline Speckled Graham & 17.3 & Brown speckled & $1.9 \mathrm{~b}$ & $1.8 \mathrm{~b}$ & $\mathrm{~S}$ & $\mathrm{R}$ \\
\hline Tyler & 12.7 & Tan & $1.2 \mathrm{c}$ & $1.1 \mathrm{c}$ & $\mathrm{R}$ & $\mathrm{R}$ \\
\hline Lalita & 11.6 & Tan & $5.0 \mathrm{a}$ & $5.0 \mathrm{a}$ & $\mathrm{R}$ & I \\
\hline $\mathrm{N}-1-3$ & 9.7 & Tan & $1.3 \mathrm{bc}$ & $1.3 \mathrm{bc}$ & $\mathrm{R}$ & $\mathrm{R}$ \\
\hline $\mathrm{N}-3$ & 11.6 & Black & $1.2 \mathrm{c}$ & $1.2 \mathrm{c}$ & I & $\mathrm{R}$ \\
\hline UCR 1340 & 12.3 & Brown mottled & $1.4 \mathrm{bc}$ & $1.4 \mathrm{bc}$ & $\mathrm{R}$ & I \\
\hline Red seed viny & 19.3 & Red & $1.1 \mathrm{c}$ & $1.1 \mathrm{c}$ & $\mathrm{S}$ & I \\
\hline Local volunteer & 6.6 & Tan mottled & $1.2 \mathrm{c}$ & $1.2 \mathrm{c}$ & I & $\mathrm{R}$ \\
\hline
\end{tabular}

${ }^{\mathrm{z}}$ Nematode index means within a column followed by the same letter are not different based on LSD at $\mathrm{P} \leq 0.05$.

${ }^{\mathrm{y}} \mathrm{AN}=$ anthracnose disease and $\mathrm{SB}=$ southern blight disease, $\mathrm{S}=$ susceptible, $\mathrm{I}=$ intermediate, and $\mathrm{R}=$ resistant.
(2001) found that cowpea genotypes varied in nitrogen content and that nitrogen content affected their nitrogen contribution to soil fertility; however, canopy biomass also affects the total nitrogen contribution.

All of the selections were indeterminate in growth habit and remained vigorous and green through the summer unless severely injured by disease. The southernpea cultivar 'Charleston Greenpack' had mature pods and was senescing at 10 to 11 weeks after planting. 'Lalita' has the shortest photoperiod of the lines included in this study. First flowers were not observed until after 15 Sept., and it consistently remained green after all the other genotypes senesced. This characteristic would reduce the risk of volunteer cowpeas becoming a weed problem for subsequent crops and would be beneficial for cowpeas grown for livestock or wildlife forage. We were able to collect seeds from Lalita in Charleston in most years; however, commercial seed production for such shortday genotypes would be restricted to subtropical areas of the United States as a result of their requirement for short photoperiods and warm temperatures.

Interestingly, all selections had relatively upright growth habits (canopy heights ranged from 52 to $65 \mathrm{~cm}$ ) (Table 1). Prostrate and semierect genotypes were eliminated in the initial screening trial, because they did not appear to compete well against weeds. This supports the conclusion of Wang et al. (2004), who found that a cowpea genotype with an upright growth habit, 'Iron Clay' was more competitive against weeds than those with semierect or prostrate growth habits. The vigorous vine growth exhibited by some genotypes also appeared to contribute to their ability to suppress weed growth. Genotypes that formed vigorous vines tended to overgrow tall annual weeds that emerged through the canopy to the extent that fewer weeds were visible in late summer. Most of the other genotypes exhibited more vigorous vine growth than 'Iron Clay' (Table 1). The combination of rapid early growth, an upright canopy, and ability to form climbing vines may contribute to a growth habit that is competitive against weeds. The methods used in the preliminary screening trial were effective for identifying cowpea genotypes suitable for use as a cover crop. Rapid evaluation tools like vigor ratings and canopy measurements are needed to facilitate breeding cowpea cultivars for use as a cover crop. Biomass measurement was quite laborious and is probably not practical for use in a large-scale breeding project.

\section{Literature Cited}

Abdul-Baki, A., J.R. Stommel, A.E. Wataba, J.R. Teasdale, and R.D. Morse. 1996. Hairy vetch mulch favorably impacts yields of processing tomatoes. HortScience 31:338-340.

Abdul-Baki, A. and J.R. Teasdale. 1995. Establishment and yield of sweet corn and snap beans in a hairy vetch mulch. Proc. Fourth National Symp. on Stand Establishment of Horticultural Crops. pp. 111-120. 
Abdul-Baki, A.A., R.D. Morse, T.E. Devine, and J.R. Teasdale. 1997. Broccoli production in forage soybean and foxtail millet cover crop mulches. HortScience 32:836-839.

Aguiar, J.L., W.A. Mathews, W.L. Graves, M. McGiffen, Jr., J.V. Samons, and J.D. Ehlers. 2001. Factor for estimating nitrogen contribution of cowpea as a cover crop. J. Agron. Crop Sci. 186:145-149.

Hall, A.E., N. Cisse, S. Thiaw, H.O.A. Elawad, J.D. Ehlers, A.M. Ismail, R.L. Fery, P.A. Roberts, L.W. Kitch, L.L. Murdock, O. Boukar, R.D. Phillips, and K.H. McWatters. 2003. Development of cowpea cultivars and germplasm by the Bean/Cowpea CRSP. Field Crops Res. 82:103134.
Harrison, H.F., D.M. Jackson, A.P. Keinath, P.C. Marino, and T. Pullaro. 2004. Broccoli production in cowpea, soybean, and velvetbean mulches. HortTech. 14:484-487.

Nangju, D. 1978. Effect of plant density, spatial arrangement, and plant type on weed control in cowpea and soybean. In: I.O. Akobundu (ed.). Weeds and their control in the humid and subhumid tropics. International Institute for Tropical Agriculture, Ibadan, Nigeria. pp. 96-104.

Remison, S.U. 1978. The performance of cowpea as influenced by weed competition. J. Agr. Sci. Cambridge. 90:523-530.

Roberts, P.A., W.C. Mathews, Jr., and J.D. Ehlers. 2005. Root knot nematode resistant cowpea cover crops for tomato production. Agron. J. 97:1626-1635.

Teasdale, J.R. and A. Abdul-Baki. 1997. Growth analysis of tomatoes in black polyethylene and hairy vetch production systems. HortScience 32:659-663.

Teasdale, J.R. and D.W. Shirley. 1998. Influence of herbicide application timing on corn production in a hairy vetch cover crop. J. Prod. Agr. 11:121-125.

Wang, G., J.D. Ehlers, E.J. Ogbuchiekwe, S. Yang, and M.E. McGifffin. 2004. Competitiveness of erect, semi-erect, and prostrate cowpea genotypes with sunflower (Helianthus annuus) and purslane (Portulaca oleracea). Weed Sci. 55:815-820. 